\title{
TANGGUNG JAWAB PENDIDIKAN ANAK PADA IBU BEKERJA MELAYU RIAU YANG MEMILIKI BALITA
}

\author{
Rini Hartati \\ rini.hartati@univrab.ac.id \\ Itto Nesyia Nasution \\ Universitas Abdurrab
}

\begin{abstract}
ABSTRAK
Penelitian ini bertujuan untuk melihat gambaran sejauh mana pemahaman Ibu Bekerja Melayu Riau tentang tanggung jawab pendidikan anak usia balita. Penelitian ini bisa bermanfaat bagi pengembangan ilmu psikologi, terkait dengan pemahaman tentang tanggung jawab Ibu dalam pendidikan anak balita. Penelitian ini menggunakan metode kualitatif dengan pendekatan fenomenologis. Teknik pengumpulan data menggunakan wawancara mendalam. Subjek dalam penelitian ini 2 orang Ibu bekerja Melayu Riau. Hasil penelitian ditemukan tentang pemahaman Ibu bekerja Melayu Riau dalam menjalankan tanggung jawab pendidikan anak dalam islam berdasarkan konsep 'Ulwan (2004) diantaranya; (1) tanggung jawab pendidikan agama, (2) tanggung jawab pendidikan moral, (3) tanggung jawab pendidikan fisik, (4) tanggung jawab pendidikan akal, (5) tanggung jawab pendidikan kejiwaan, dan (6) tanggung jawab pendidikan sosial.
\end{abstract}

Kata Kunci: Ibu Bekerja, Melayu Riau, Pendidikan anak

\section{PENDAHULUAN}

Pendidikan utama yang diperoleh anak adalah pendidikan dari keluarga. Keluarga merupakan tempat mendidik anak agar memiliki pengetahuan, pengalaman dan perilaku yang baik. Maka dari itu tugas keluarga merupakan suatu yang sangat penting yakni menciptkan proses pendidikan yang berkelanjutan (continues progress) dalam suasana keluarga. Orang tua harus memahami dengan baik kewajiban dan tanggung jawab orang tua dalam hal pendidikan ini (Jailani, 2014). Salah satu orang tua yang sangat berperan dalam pendidikan anak adalah Ibu, karena Ibu merupakan orang yang terdekat dan paling utama dalam pengasuhan anak. Keutamaan Ibu mengasuh anak bisa dilihat dari firman Allah SWT dalam Al-Quran surat Al-Baqarah ayat 233 ("Para Ibu hendaklah menyusukan anak-anaknya selama dua tahun penuh, yaitu bagi yang ingin menyempurnakan penyusuan") yaitu memberikan kebutuhan dasar awal mula kehidupan manusia di dunia yaitu Air Susu Ibu (ASI). Adanya kebutuhan dasar akan ASI pada bayi secara tidak langsung memberikan tanggung jawab kepada Ibu untuk selalu berada dekat dengan anak. Proses interaksi yang terus berlangsung antara Ibu dan anak merupakan proses pendidikan.

Menurut Depkes RI, 2009b (dalam Aji, D. S. K., Wati, E. K., \& Rahardjo, S, 2016) Ibu merupakan salah satu anggota keluarga yang sangat menentukan perkembangan balita, baik dari perkembangan fisik, emosi, dan sosial 
berdasarkan kualitas dan kuantitas dari interaksi antara orang tua dengan anak, bagaimana pola mendidik anak, pemberian perhatian dan pemenuhan kebutuhan anak. Sehingga untuk menjalankan peran sebagai Ibu tentu membutuhkan pengetahuan, waktu dan tenaga, oleh karena itu tidak semua Ibu bisa menjalankannya secara maksimal, terutama bagi Ibu yang bekerja. Ibu yang bekerja memiliki tanggung jawab mengurus rumah tangga dan juga memiliki tanggungjawab mengurus pekerjaan di luar rumah. Adanya dua tanggung jawab yang dijalani Ibu bekerja dalam waktu yang bersamaan tentu akan memiliki konsekuensi, dimana kedua tanggung jawab tersebut tidak bisa dikerjakan secara maksimal. Ibu yang sedang menjalankan tanggung jawab pekerjaan di luar rumah, tidak akan bisa menjalan tanggung jawab pekerjaan peran sebagai Ibu dalam mengasuh dan mendidik anak. Begitu juga sebaliknya, Ibu yang lebih mengutamakan mengasuh dan mendidik anak, tentunya juga tidak akan maksimal menjalankan amanah pekerjaan di luar rumah.

Waktu yang lama meninggalkan anak karena tuntutan pekerjaan, tentu akan berpengaruh pada kelekatan dengan anak. Kelekatan orang tua terutama Ibu dengan anak sangat penting. Menurut Bowlby (dalam Lestari, 2014) perilaku pengasuhan sebagai faktor kunci dalam hubungan orang tua-anak yang dibangun sejak dini. Pada masa awal kehidupannya anak mengembangkan hubungan emosi yang mendalam dengan orang dewasa yang secara teratur merawatnya. Hubungan emosi yang mendalam ini akan berpengaruh kepada perkembangan anak kedepannya. Meskipun demikian, fenomena yang terlihat di masyarakat adalah tuntutan pekerjaan Ibu di luar rumah mengakibatkan Ibu tidak bisa menjalankan peran dan tanggung jawabnya sebagai Ibu secara maksimal.

Tugas utama Ibu sebagai pengasuh dan mendidik anaknya banyak dijumpai dalam berbagai literatur, diantaranya menurut 'Ulwan (2014) mengatakan bahwa Ibu memiliki kewajiban untuk memenuhi kebutuhan dan memberikan pendidikan kepada anaknya, dan salah satu kebutuhan bagi balita adalah kasih sayang yang diberikan oleh orang tuanya secara langsung. Senada dengan itu, Hawari (dalam Hartati, 2018) juga menyampaikan bahwa perempuan lebih utama mengurus keluarganya dibandingkan dengan karirnya. Pandangan tentang keutamaan mengasuh dan mendidik anak ini juga sejalan dengan budaya Melayu Riau. Effendi (2004) mengatakan bahwa mendidik dan membela anak sangat diutamakan dalam budaya Melayu, dengan tujuan supaya anaknya menjadi orang yang sempurna secara lahiriah dan batiniah. Mendidik anak dilakukan secara langsung, tidak hanya berupa nasehat tapi juga memberikan contoh perilaku dari orang tuanya, sehingga orang tua bisa menjadi tauladan bagi anak.

Orang tua terutama Ibu Melayu Riau bisa menerapkan pola asuh yang sesuai dengan budaya Melayu Riau, jika Ibu bisa memaksimalkan waktu dan tenaga untuk mengasuh dan mendidik anaknya, sehingga peran sebagai seorang Ibu dapat berfungsi secara optimal. Ibu sebagai orang yang menjalankan peran dan tanggung jawab dalam mendidik anak membutuhkan pemahaman tentang konsep pendidikan anak. Sehingga dengan pemahaman itu Ibu memiliki rasa tanggung jawab untuk melaksanakan peran dalam mendidik anak. 
Berdasarkan latar belakang tersebut, maka yang menjadi fokus penelitian ini adalah "Bagaimana gambaran dari pemaham Ibu terkait dengan pendidikan anak pada Ibu bekerja Melayu Riau yang memiliki balita?"

\section{METODOLOGI}

Penelitian ini menggunakan metode kualitatif dengan pendekatan fenomenologis, yaitu dengan mendeskripsikan tentang pemaknaan dari sejumlah individu berbagai pengalaman hidup yang mereka rasakan terkait dengan konsep atau fenomena yang diangkat. Subjek dalam penelitian ini terdiri dari 2 orang Ibu bekerja Melayu Riau yang memiliki balita. Adapun metode pengambilan sampelnya adalah purposive sampling, yaitu teknik penentuan sampel dengan pertimbangan tertentu, yakni orang yang dianggap paling tau tentang apa yang diharapkan sehingga akan memudahkan peneliti menjelajahi objek/situasi yang diteliti (Sugiyono, 2011). Penelitian ini melakukan pengambilan data dengan menggunkan wawancara terstruktur berdasarkan konsep menurut 'Ulwan, 2014.

\section{HASIL PENELITIAN}

Subjek pertama adalah S, berusia 38 tahun dan bekerja sebagai Pegawai Negeri Sipil. S mulai bekerja dari tahun 2002. S memiliki 3 orang anak dengan salah satunya berusia 3 tahun. S berangkat kerja dari rumah jam 07.00 WIB dan pulang sampai di rumah jam 17.00 WIB. S juga menambah kegitannya dengan pergi senam sebanyak satu kali dalam seminggu, dari pulang kerja sampai magrib. Pada saat S pergi bekerja, S menitipkan anaknya ke Ibu S. Jika suami S sedang di rumah, maka $S$ meninggalkan anaknya bersama suaminya.

Tanggung jawab S dalam pendidikan anak dirasakan S kurang maksimal, ini disebabkan karena keterbatasan waktu bersama anak. Temuan terkait dengan pasal pertama tentang pendidikan iman, S memahami bahwa Ibu bertanggung jawab mendidik anak dengan memperkenalkan ibadah sholat disaat waktu sholat bersama S. Waktu sholat yang sering dilakukan di dekat anak seperti sholat magrib. S mengajarkan anak dengan menyediakan perlengkapan sholat anak seperti sajadah ukuran kecil dan peci. S membiarkan anak ikut sholat bersama S. S juga memberikan fasilitas seperti mainan berupa rekaman suara tentang lagu-lagu islami. Selain dari itu terkait dengan ibadah-ibadah lainnya $S$ cukup menjelaskan kegiatan ibadah disaat kegiatan itu di lakukan, misalkan di bulan puasa, anak $S$ terbangun di saat jam sahur, maka S menjelaskan bahwa $S$ akan berpuasa. Begitu juga dengan bersedekah, $\mathrm{S}$ menjelaskan kepada anak disaat waktu bersedekah. S memahami bahwa pendidikan iman hanya bisa dilakukan disaat $\mathrm{S}$ sedang menjalankan aktivitas ibadah, karena $\mathrm{S}$ beranggapan bahwa anak belum bisa mengerti karena masih kecil.

Pendidikan moral pada pasal kedua, $\mathrm{S}$ memahami tanggung jawab dari Ibu adalah dengan menjelaskan di saat $\mathrm{S}$ sedang melihat anaknya melakukan perilaku yang kurang baik, misalnya anak S mengambil barang milik orang lain, maka S melarang, namun jika anak S mengambil barang milik saudaranya S lebih sering membiarkan dan meminta saudaranya untuk mengalah. Berkaitan dengan stimulus lingkungan seperti media (televisi, hp) yang akan mempengaruhi perilaku anak, S kurang mengontrol, karena S berangapan bahwa anaknya 
memang kurang suka menonton televisi, sedangkan hp S juga membiarkan, karena juga beranggapan bahwa anaknya tidak tergolong candu, jika sudah bosan anaknya meninggalkan hp tersebut. Secara umum S memahami bahwa pendidikan moral pada anak cukup dilakukan dengan menegur anak jika melakukan perilaku yang tidak baik.

Pasal ketiga tentang pendidikan fisik, S memahami bahwa S harus menyediakan makanan yang sehat untuk anaknya. S berusaha menghindari memberikan makan instan. S lebih sering menyiapkan makan yang dimasak langsung oleh S. Pada waktu anak S bayi, S berusaha memberikan ASI kepada anaknya. Jika S pergi bekerja, maka ASI dipompa. Namun S pernah mencoba memberikan susu formula disaat anak S berusia 1 tahun, meskipun sebenarnya $\mathrm{S}$ masih memiliki ASI yang banyak, tapi pada waktu itu anak S tidak menyukainya, sehingga ASI bisa diberikan sampai anak $S$ berusia 2 tahun. Pada waktu memberhentikan ASI, S melakukan dengan mengoleskan zat bewarna dan memiliki rasa pahit, sehingga anak $S$ terpaksa berhenti ASI. Berkaitan dengan makan, S mengatakan bahwa sekarang anak S tidak lagi menyukai sayur, dalam menyikapi masalah ini S kadang-kadang menyuapkan sedikit sayur di saat anak $S$ terlengah. Sebenarnya S memahami bahwa sayur penting untuk anak, apalagi anak S pernah mengalami kesulitan dalam buang air besar, tapi S merasa tidak punya cara dan membiarkan, yang terpenting bagi $S$ anaknya kenyang, selain dari itu S juga mengakui bahwa S tidak memiliki waktu untuk membujuk atau melatih anaknya untuk makan sayur.

Pendidikan akal pada pasal keempat, S melakukan mendidik anak dengan menyebutkan benda-benda yang ditemui bersama anak, seperti ketika melihat binatang disaat bermain di luar atau melihat binatang pada gambar atau video. S tidak memiliki perencanaan atau target dalam hal ini. S memahami bahwa anak $\mathrm{S}$ belajar cukup dengan perjalanan waktu pada kegiatan sehari-hari saja. Pada pendidikan kejiwaan dan sosial, S melatih keberanian anak dengan mengajarkan kepada anak untuk mau bersalaman dengan orang baru yang ditemui anaknya seperti tamu dari teman-teman $S$ yang datang berkunjung kerumah. S merasa anak $\mathrm{S}$ memiliki sifat individual, lebih senang bermain sendiri dibandinkan dengan teman-temannya.

Subjek kedua adalah Y, berusia 37 tahun, bekerja sebagai pegawai honorer di sebuah dinas pemerintahan, Y bekerja mulai dari tahun 2006. Y memiliki 4 orang anak, 2 diantaranya berusia 4 tahun dan 1 tahun 7 bulan. Pada waktu Y pergi bekerja, anak Y dititipkan kepada pengasuh. Y memiliki beberapa orang pengasuh anak yang berhenti dengan sendirinya secara bergantian. Pengasuh anak Y berhenti bukan karena diberhentikan oleh Y, tapi memang pengasuh $\mathrm{Y}$ minta berhenti sendiri. Y tidak mau memberhentikan pengasuh anaknya meskipun pengasuh tersebut pernah memarahi anak $Y$ dengan memukul, alasan Y adalah karena merasa tidak tega, melihat adanya kebutuhan pengasuh tersebut terhadap pekerjaan itu. Y memaklumi jika pengasuh anaknya memarahi dengan memukul karena Y mengerti kesulitan mengasuh dengan 4 orang anak.

Y berangkat bekerja dari jam 07.00 sampai jam 17.00 WIB. Jika pekerjaan tidak banyak, Y menyempatkan untuk pulang ke rumah pada jam istirhat, karena rumah Y cukup dekat dengan kantor tempat Y bekerja. Secara umum Y merasa 
tidak keberatan dengan kondisi harus meninggalkan anak untuk pergi bekerja, karena Y melihat anaknya lebih baik perilakunya disaat Y tidak bersama mereka. Ketika anak Y berada bersama Y, mereka lebih sering bertengkar, "cengeng", menuntut banyak hal kepada Y. Bahkan pada malam hari, salah satu dari anak Y melarang Y untuk tidur terlebih dahulu sebelum mereka tidur, sementara anak Y sering tidur pada jam tengah malam, sehingga Y merasa kurang waktu istirahat.

Tanggung jawab pendidikan anak menurut $Y$ sangat penting, meskipun $Y$ dapat melakukannya hanya ketika bersama anak. Pendidikan anak yang paling utama bagi Y adalah pendidikan agama. Y memiliki target untuk menyekolahkan semua anakanya di sekolah agama. Y memahami cara mendidik anak dalam bidang agama dengan mengikutsertakan Allah SWT dalam setiap aktivitas anak. Seperti ketika mau menasehati anak untuk jujur, Y mengatakan bahwa Allah melihat setiap kegiatan kita. Selain dari itu Y juga mengajarkan anak untuk menjalankan ibadah seperti berdoa sebelum makan, mengajak anak untuk sholat dan mengaji.

Pada pendidikan moral, Y memahami bahwa hal yang perlu ditekankan adalah menjaga untuk tetap berperilaku baik, tapi Y menyadari bahwa perilaku anaknya masih sering bertengkar dan sulit diatur. Begitu juga kontrol dari media seperti televisi, Y juga menyadari bahwa anaknya masih suka menonton film-film kartun yang tidak mendidik. Y tidak bisa mengontrol terutama di saat $Y$ sedang pergi bekerja. Akhirnya anak Y juga cenderung mengikuti gaya tokoh-tokoh yang ada di film kartu. Anak Y juga meminta dibelikan mainan berupa tokoh dalam film lkartun tersebut. Di sisi lain Y juga mengajarkan kepada anaknya untuk berbelanja sesuai dengan jangkauan harga. Y mengajarkan dengan menjelaskan konsekuensi jika berbelanja maianan dengan harga yang mahal, sehingga anak $Y$ bisa mengikutinya.

Pada Pendidikan Fisik, Y memahami penting untuk menajaga kesehatan anaknya melalui makanan. Y mengajarkan anaknya makan dengan masakan Y sendiri, sehingga $Y$ merasa anak $Y$ jarang memakan makanan yang instan, tapi $Y$ tidak bisa mengontrol di saat Y bekerja di kantor. Selain dari itu Y juga mengalami kesulitan mengontrol pola tidur anak-anaknya, karena anak-anak Y bisa tidur setelah jam 11.00 malam.

Pendidikan akal, Y memahami hal yang perlu diajarkan adalah pengenalan nama-nama benda melalui buku atau televisi. Pendidikan ini memang jarang Y lakukan karena keterbatasan waktu Y. Sehingga Y sering heran jika mendapati anak Y punya cara sendiri untuk melakukan seperti bercerita melihat isi gambar pada buku-buku kakaknya. Sedangkan pada pendidikan kejiwaan Y dan sosial, Y merasa kesulitan dalam mengatur emosi anaknya, terkadang Y merasa anaknya sulit untuk dibujuk, sifat anak Y lebih cenderung keras.

\section{DISKUSI}

Pendidikan anak pada usia balita sangat penting. Interaksi yang dilakukan orang tua, terutama Ibu sangat membangun perkembangan yang baik pada anak. Interaksi pertama dilakukan mulai dari anak dalam kandungan, kemudian dilanjutkan ketika bayi sedang menyusu kepada Ibunya dan sampai anak masuk usia sebelum sekolah. Interaksi ini akan membangun kelekatan emosional antara 
anak dengan Ibu. Kelekatan itu akan menumbuhkan kepercayaan anak kepada Ibunya, sehingga Ibu bisa mendidik dan membimbing anak dengan mudah. Jika kelekatan tidak dibangun oleh Ibu, maka akan menyulitkan Ibu untuk mendidik atau membimbingnya, karena tidak adanya ikatan emosional yang menumbuhkan kepercayaan anak.

Menurut Bowlby (dalam Feist J \& Feist G, 2008) kelekatan yang terbentuk selama masa kanak-kanak memiliki pengaruh yang sangat penting bagi kepribadian masa dewasa. Pada teori Bowlby, menemukan ada tiga tahapan dari kecemasan terhadap keterpisahan (separation anxiety). Pertama adalah "tahap protes", yaitu ketika pengasuhnya pertama tidak terlihat, bayi akan menangis menolak dihibur orang lain, dan mencari pengasuhnya. Kedua "tahap putus asa", ketika perpisahan berjalan terus, bayi mulai diam, sedih, pasif, tidak bergerak, dan muram. Kemudian tahap ketiga yaitu "tahap menjauhkan diri" (detachment), selama tahapan ini bayi mulai menjauhkan diri secara emosional dari siapapun, termasuk pengasuhnya. Jika pengasuh mereka (Ibu) kembali, bayi akan cuek dan malah berusaha menghindarinya. Anak-anak yang menjauhkan diri ini tidak lagi merasa marah ketika Ibu meninggalkan mereka. Kemudian ketika mereka tumbuh dewasa mereka akan bermain dan berinteraksi dengan orang lain dengan sedikit saja melibatkan emosi namun terlihat seperti bersosialisasi. Hubungan antara pribadi mereka cendrung dibuat-buat dan kurang mengandung kehangatan.

Berdasarkan teori yang disampaikan oleh Bowlby (dalam Feist J \& Feist G, 2008), bahwa perkembangan emosi sangat penting. Perkembangan emosi yang baik akan mempengaruhi proses pendidikan anak. Anak akan lebih mudah memahami stimulus ketika pada diri anak merasakan kenyaman dan kepercayaan dengan orang lain. Ibu bekerja akan memiliki kendala dalam membantu perkembangan emosi anaknya. Faktor ini disebabkan diantaranya, yang pertama terjadinya proses separation anxiety atau kecemasan terhadap keterpisahan. Ketika ibu pergi dan meninggalkan anak untuk bekerja, bayi akan mendapati situasi yang berbeda, misalnya bayi yang biasa diberikan ASI langsung dari Ibunya, maka disaat Ibunya pergi bayi harus beradaptasi dengan dot, sehingga bayi merasa tidak nyaman. Adanya proses tidak nyaman ini akan mempengaruhi perkembangan psikologis bayi. Kedua, disaat bayi tidak menyusu langsung kepada Ibunya, maka terputuslah kesempatan untuk berinteraksi antara Ibu dengan bayi, sehingga akan mempengaruhi kelekatan. Ketiga, jika bayi tidak mendapati sumber afeksi atau kasih sayang yang tepat sebagai pengganti Ibu disaat Ibu pergi bekerja, maka proses perkembangan emosi bayi akan terhambat, karena kurangnya stimulus yang diberikan.

Berdasarkan hasil penelitian pada subjek $S$ dan Y mengalami kondisi dimana tidak bisa secara maksimal dalam memberikan ASI. Subjek S bisa memberikan ASI sampai usia anak 2 tahun, namun $S$ memberikan ASI tidak secara langsung tapi melalui dot disaat $\mathrm{S}$ bekerja di kantor. S merasakan kurang kesempatan untuk berinteraksi dengan anak terutama interaksi waktu menyusui dan juga kesempatan berinteraksi di siang hari karena S harus bekerja. Tapi di sisi lain $S$ merasa perlu bekerja, dan menerima kondisi itu sebagai suatu konsekuensi. Begitu juga dengan subjek Y, Y dapat memberikan ASI kepada anaknya cuma pada 5 bulan pertama, setelah itu, anak Y diberikan susu formula 
karena ASI Y tidak mencukupi. Y juga beranggapan bahwa ini merupakan suatu konsekuensi yang harus dijalani. Meskipun kedua suami subjek S dan Y tetap memenuhi nafkah keluaraga, namun kedua subjek merasa butuh bekerja untuk menambah penghasilan keluarga.

Teori kelekatan yang disampaikan oleh Bowlby, jika dianalisa terhadap kedua subjek. Kelekatan mempengaruhi perkembangan emosi anak. Pada subjek $\mathrm{S}$, ditemukan beberapa data terkait kurang interaksi antara $\mathrm{S}$ dengan anak, seperti ketika S mau berhenti menyapih anaknya. S melakukan dengan cara mengoleskan zat-zat yang pahit dan warna yang mencolok, disertai dengan penyampaian informasi yang tidak benar kepada anak dengan tujuan anak $S$ tidak mau menyusu lagi. Perilaku ini membuat anak S kaget dan menangis. Proses pemberhentian penyapihan dengan cara seperti ini, akan memunculkan kondisi emosi yang tidak baik kepada anak. Banyak pengalaman para Ibu yang didapatkan bahwa, perilaku anak pada saat seperti ini sangat berbeda, dimana anak menangis dengan kencang, kemudian memberotak, marah dan lain sebagainya. Hal ini tentunya wajar terjadi pada anak, karena anak merasa kaget, dan dengan kepekaan seorang anak, anak merasa tertipu sehingga mempengaruhi kurangnya kepercayaan kepada Ibu. Jika interaksi dibangun secara baik oleh Ibu, tentu proses pemberhentian penyapihan kepada anak dengan cara seperti ini tidak mungkin terjadi. Interaksi yang dibangun secara baik itu akan membuat perilaku Ibu untuk berusaha jujur kepada anaknya.

Menurut 'Ulwan (2014), orang tua memiliki tanggung jawab dalam mendidik anak. Tanggung jawab dalam pendidikan anak dalam islam terdiri dari tujuh pasal, diantaranya; pertama tanggung jawab pendidikan iman, kedua tanggung jawab pendidikan moral, ketiga tanggung jawab pendidikan fisik, keempat tanggung jawab pendidikan akal, kelima tanggung jawab pendidikan kejiwaan, keenam tanggung jawab pendidikan sosial, dan ketujuh tanggung jawab pendidikan seks. Pada penelitian ini yang dibahas hanya enam tanggung jawab pendidikan saja, tanggung jawab pendidikan seks tidak dibahas karena subjek penelitian balita.

Pasal pertama tentang tanggung jawab pendidikan iman dijelaskan bahwa pendidik mengajarkan kepada anak tentang keyakinan akan adanya Allah SWT sebagai pencipta dan pengatur seluruh alam semesta, memberikan pemahaman kepada anak bahwa manusia diciptakan untuk mengabdi kepada Allah SWT serta tujuan manusia hidup adalah untuk beribadah, dan ada kehidupan akhirat untuk mempertanggungjawabkan perilaku selama kehidupan di dunia. Pemahaman ini perlu diketahui anak sejak usia dini, menjelaskan sesuai dengan perkembangan anak. Pada pasal kedua tentang tanggung jawab pendidikan moral, yaitu mengajarkan sikap yang baik kepada anak, akhlak yang lurus serta memiliki kepribadian islami, seperti menghindarkan anak dari perilaku ikut-ikutan (taqlid buta), mencegah agar tidak tenggelam dalam kesenangan, melarang mendengarkan musik dan nyanyian yang tidak baik, melarang berpenampilan yang tidak sesuai dengan identitas diri, mengajarkan untuk menjaga aurat. Pasal ketiga tentang tanggung jawab pendidikan fisik yaitu bagaimana menjaga dan merawat fisik anak sehingga memiliki fisik yang sehat, kuat dan bersemangat. Tanggung jawab ini diantaranya: mengajarkan anak untuk mengikuti aturanaturan kesehatan dalam makan dan minum, membentengi diri dari penyakit 
menular, menerapkan prinsip tidak boleh membahayakan diri sendiri dan orang lain, membiasakan anak agar gemar berolah raga, membiasakan anak untuk zuhud dan tidak larut dalam kenikamatan, menanamkan karakter bersungguhsungguh dan perwira kepada anak. Pasal keempat tanggung jawab pendidikan akal, yaitu membentuk pola berpikir anak terhadap segala sesuatu yang bermanfaat baik berupa ilmu syar'i, ilmu modern, kesadaran pemikiran, dan peradaban. Pasal kelima tentang pendidikan kejiwaan yaitu mendidik anak agar berani dan berterus terang, tidak takut, mandiri, suka menolong orang lain, mengendalikan emosi, dan menghiasi diri dengan segala bentuk kemuliaan diri baik secara kejiwaan dan akhlak secara mutlak. Pasal keenam tantang tanggung jawab sosial yaitu mengajarkan anak pada etika sosial yang utama, dan dasardasar kejiwaan yang mulia bersumber dari akidah islam yang abadi dan perasaan keimanan yang tulus, misalnya persaudaraan atas dasar kicantaan kepada Allah SWT.

Berdasarkan data penelitian yang didapat, pemahaman kedua subjek penelitian tentang tanggung jawab pendidikan anak belum dipahami secara maksimal. Kedua subjek penelitian lebih memahami tanggung jawab pendidikan anak hanya sebatas pemenuhan kebutuhan fisik saja, yang terpenting anak terpenuhi kebutuhan dasarnya, seperti kebutuhan akan keamanan secara fisik, kebutuhan makan, minum dan kebutuhan mainan serta fasilitas lainnya. Pemahaman akan kebutuhan mendasar lainnya seperti kebutuhan akan pemenuhan kasih sayang, interaksi yang bersifat mendidik secara kontiniu dan pemahaman akan konsep dasar islam belum dipahami secara maksimal. Kurangnya pemahaman orang tua terutama Ibu bekerja tentang kebutuhan dan pendidikan anak ini akan menghambat perkembangan anak secara baik. Berdasarkan hasil penelitian dari Muntiani dan Supartini (2013), didapatkan bahwa perkembangan balita dengan Ibu bekerja berada pada posisi yang meragukan. Ini dijelaskan karena adanya keterbatasan interaksi antara Ibu dengan anak, sehingga perhatian dan kasih sayang diberikan kepada anak tidak maksimal.

Ibu bekerja akan lebih banyak menghabiskan waktu dan pikiran ke pekerjaan, sehingga akan mengurangi kesempatan ibu untuk membimbing dan mendidik anaknya. Sedangkan proses pendidikan anak terutama balita membutuhkan waktu yang bersifat kontiniu yang disertai dengan transfer kebutuhan mental lainnya seperti kasih sayang, kepercayaan, kenyamanan dan lain-lain. Proses pendidikan ini membutuhkan metode supaya tujuan pendidikan itu bisa tercapai dengan baik. Berdasarkan penelitian dari Syahraeni (2015), terdapat beberapa metode dalam mendidik anak, diantaranya; metode percakapan atau dialog, metode kisah, metode perumpamaan, metode keteladanan, dan metode pembiasaan.

Anak usia balita memiliki kemampuan untuk memahami sesuatu jika dijelaskan dengan cara atau metode yang tepat, misalnya, bayi usia kurang dari 2 tahun yang akan berhenti menyusu ASI. Ibu menyampaikan dan menjelaskan kepada anak dengan komunikasi yang dimerngerti anak sesuai perkembangan usianya, kemudian proses ini dilakukan secara bertahap supaya anak tetap tenang dan tidak terkejut akan terjadinya perubahan. Menjalankan metode seperti ini tentu membutuhkan waktu dan pemahaman Ibu terkait dengan cara 
komunikasi dan kepekaan Ibu melihat respon dari anaknya. Bagi Ibu bekerja akan memiliki kesempatan yang lebih kecil untuk menjalankan tanggung jawab dalam mendidik anak secara tepat dan baik, karena keterbatasan waktu untuk belajar memahami dan menajalankan peran amanah pendidikan tersebut. Ibu yang memilih untuk bekerja harus menerima konsekuensi ini, dimana kesempatan untuk menjalankan amanah dan tanggung jawab yang lebih utama terabaikan, dan keputusan memilih bekerja ini tentu dilatar belakangi oleh beberapa faktor, diantaranya; kecemasan Ibu akan kurangnya finansial untuk memenuhi kebutuhan keluarga, dan kebutuhan Ibu untuk mengaktualisasikan diri di masyarakat. Meskipun disisi lain adanya perasaan kurang nyaman disaat memilih untuk menjalankan konsekuensi ini, yaitu mengurangi hak anak untuk mendapatkan pengasuhan dan pendidikan dari Ibu.

Perasaan kurang nyaman yang dirasakan Ibu disaat memilih untuk meninggalkan anaknya karena pergi bekerja merupakan sinyal fitrah diri yang diberikan Allah SWT, karena Allah SWT memerintahkan untuk menjalankan amanah terhadap pendidikan anak. Anak merupakan amanah dari Allah SWT yang akan dipertanggung jawabkan kelak di akhirat. Ini sejalan dengan kebudayaan melayu Riau yang tertuang dalam tunjuk ajar melayu. Budaya melayu Riau dikembangkan dari ajaran Islam, termasuk kepada aturan dalam pendidikan anak. Pada tunjuk ajar melayu Riau dikatakan bahwa mendidik dan membela anak sangat diutamakan dalan budaya melayu, tujuan utama mendidik anak adalah agara anak menjadi "orang", yakni menjadi manusia yang sempurna lahiriah dan bathiniah, ini merupakan kewajiban yang harus dilaksanakan kerena perintah dari agama Islam dan adat lembaga. Banyak petuah amanah berkaitan dengan anak yang diwariskan dalam budaya Melayu (Effendi, 2004), diantaranya :

kalau hendak mendidik anak, petuah amanah hendaklah simak:

mendidik anak sebelum nampak

membela anak sebelum berupa

anak dididik sejak kecil

anak diajar sejak terpancar

anak dibela selamanya

hutang bela dengan pelihara

hutang tunjuk dengan ajar

hutang petuah dengan amanah

hutang contoh dengan teladan

Petuah amanah dalam tunjuk ajar Melayu, menjelaskan bahwa pendidkan anak merupakan kewajiban bagi orang tuanya, yang dinilai sebagai amanah atau hutang yang harus dilaksanakan. Proses pendidikan ini dimulai sejak anak ada terutama setelah lahir. Salah satu metode dalam pendidikan anak pada tunjuk ajar melayu adalah metode keteladanan, dimana orang tua menunjukkan secara langsung perilaku yang mesti diadaptasi oleh anak, karena anak terutama usia balita proses pembelajaran dilakukan secara modeling atau peniruan. Berdasarkan penelitian dari Fitri dan Widyastuti (2017), dijelaskan bahwa orang tua memiliki tanggung jawab dalam mendidik anak, masing-masing orang tua memiliki tugas dan perannya. Ibu yang menajalankan amanah memiliki peran 
mengasuh anak dan merawat keluarganya. Ibu juga memiliki tanggung jawab untuk menjalankan fungsi psikologisnya yaitu memberikan kasih sayang, rasa aman, dan perhatian kepada anaknya yang diistilahkan sebagai benevolance. Apabila orang tua terutama Ibu, betul-betul memahami tanggung jawab dan peran utama dari tugas seorang Ibu yaitu mengutamakan dalam pengasuhan dan pendidikan anaknya, kemudian Ibu memiliki pemahaman yang konkrit terkait dengan pendidikan anak secara islami dan juga sesuai dengan tunjuk ajar Melayu, maka pilihan untuk meninggalkan dan menitipkan anak disaat pergi bekerja akan menjadi pertimbangan yang sangat besar. Dari hasil penelitian didapatkan bahwa capaian pemahaman Ibu terkait tanggung jawab pendidikan anak belum maksimal, sehingga peran dan tanggung jawab terhadap pendidikan anakpun belum terlaksana secara maksimal.

\section{KESIMPULAN}

Penelitian ini dapat disimpulkan bahwa tanggung jawab pendidikan anak merupakan amanah yang diberikan kepada orang tua terutama Ibu sebagai peran utama dalam pengasuhan anak. Ibu harus memiliki pemahaman yang konkrit terkait dengan tanggung jawab pendidikan anak, diantaranya tanggung jawab apa saja yang harus di ajarkan dari segi agama, moral, fisik, kejiwaan, akal dan sosial. Ibu harus memahami sampai batasan mana yang mesti harus dipahami anak. Selain dari itu, Ibu juga harus memiliki pemahaman dan kemampuan metode dalam mendidik anak sesuai dengan perkembangan usia anak, sehingga tujuan dari pendidikan itu bisa tercapai dengan baik. Ibu bekerja memiliki keterbatasan waktu dan kesempatan dalam menjalankan tanggung jawab pendidikan anak, sehingga anak diasuh dan dididik oleh pengganti Ibu. Pilihan ini merupakan suatu dilema bagi diri Ibu yang memunculkan perasaan tidak nyaman. Perasaan tidak nyaman ini merupakan sinyal fitrah dari Allah SWT atas konsekuensi kurang menjalankan amanah tanggung jawab pendidikan anak secara maksimal. Amanah tanggung jawab pendidikan anak sudah dituangkan dalam tunjuk ajar Melayu, dimana orang tua memiliki hutang untuk mendidik anaknya. Maka dari itu sebaiknya Ibu terutama Ibu bekerja berusaha untuk lebih memahami peran dan tanggung jawab pendidikan anak.

\section{DAFTAR PUSTAKA}

Abidin, Z. 2006. Penyusuan dan perkembangan Anak. Jurnal Psikologi Islami. $4(2), 117-124$.

Aji, D. S. K., Wati, E. K., \& Rahardjo, S. (2016). Analisis Faktor-faktor yang Berpengaruh Terhadap Pola Asuh Ibu Balita di Kabupaten Banymas. Jurnal Kesmas Indonesia 8 (1), 2-3.

Effendy, T. 2004. Tunjuk Ajar Melayu (Butir-butir Budaya Melayu Riau). AdiCita: Yogyakarta.

Feist, J \& Feist, G. J. (2008). Theories of Personality. Yogyakarta: Pustaka Pelajar.

Fitri, A. R \& Widyastuti, A. 2017. Orang Tua Yang Amanah : Tinjauan Psikologi Indijinus. Jurnal Psikologi Sosial 15 (1), 12-24.

Hartati, R. (2018). Hubungan Antara Religiusitas dengan Self Concept Pada Ibu Bekerja yang Memiliki Balita. Jurnal Psychopolytan 2 (1), 49-57. 
Hasan, Y. 2014. Melusuri Asal Usul Bangsa Melayu. Jurnal Pendidikan Sejarah Criksetra 13 (1), 27-32.

Husaini, A. 2018. Pendidikan Islam Mewujudkan Generasi Gemilang Menuju Negara Adidaya 2045. Jawa Barat: Yayasan Pendidikan Islam At-taqwa Depok.

Jailani, M. S. (2014). Teori Pendidikan Keluarga dan Tanggung Jawab Orang Tua dalam Pendidikan Anak Usia Dini. Jurnal Pendidikan Islam 8 (2), 247-248.

Lestari, S. 2014. Psikologi Keluarga. Kencana: Jakarta.

Muntiani \& Supartini. 2013. Hubungan Ibu Bekerja Dengan Perkembangan Balita Usia 4-5 Tahun di TK Dharma Wanita Desa Grogol Kecamatan Tulangan Kabupaten Sidoarjo. Embrio Jurnal Kebidanan 3, 46-32.

Subandi, M. A. 2013. Psikologi Agama \& Kesehatan Mental. Yogyakarta: Pustaka Pelajar.

Sugiyono. 2011. Metode Penelitian Kuantitatif, Kualitatif dan R\&D. Bandung: Alfabeta. Thouless, Robert H. 1992. Pengantar Psikologi Agama. Jakarta: CV Rajawali.

Syahraeni, A. (2015). Tanggung Jawab Keluarga Dalam Pendidikan Anak. Jurnal Bimbingan Penyuluhan Islam Al-Irsyad Al-Nafs 2 (1), 27-45.

'Ulwan, A. N. (2014). Pendidikan Anak Dalam Islam. Solo: Insan Kamil. 